Marta Verginella*

\title{
Ženske $v$ vojni in o véliki vojni
}

\section{IZVLE $\check{C} E K$}

Članek se ukvarja z vplivi prve svetovne vojne na odnose med spoloma. Je vojna prinesla več svobode, lažji dostop do trga delovne sile in večjo vlogo v družbi, ko so ženske ob splošni mobilizaciji moških prevzemale vedno več nalog in obveznosti? Iz panoramskega pregleda najbolj referenčnih opravljenih študij je razvidno, da dokončne razlage ni. Z véliko vojno so se ženskam dejansko odprle nove priložnosti za dejavnosti v številnih delih Evrope, tudi v slovenskih deželah, vendar so politične in upravne oblasti velikokrat skušale onemogočiti radikalnejše spremembe vlog spolov v družbi.

Ključne besede: prva svetovna vojna, ženske, zgodovina spola, avtobiografski viri, intelektualke

\section{ABSTRACT}

WOMEN IN WAR AND THEIR OUTLOOK ON THE GREAT WAR

The article focuses on the impacts of World War I on the gender relations. Did the war bring more freedom, easier labour market access and greater role of women in the society, as the duties and obligations of women increased along with men's general mobilisation? The panoramic overview of the most referential existing studies comes to a conclusion that there is no unequivocal explanation. The Great War indeed offered new opportunities for women's activities in many places around Europe, including the Slovenian lands, whereas political and administrative powers often tried to prevent the more radical changes of gender roles in the society.

Keywords: World War I, women, history of gender, autobiographical sources, intellectuals

$\mathrm{V}$ zadnjih dvajsetih letih je prva svetovna vojna postala pomembno raziskovalno polje slovenskega zgodovinopisja. Poleg vojaških in političnih vidikov vojnega spopada so predmet raziskav postali tudi socialni in kulturni vidiki vojne ter materialne in nematerialne posledice vojnega dogajanja na Slovenskem. Pregled doslej opravljenega zgodovinopisnega dela pokaže, da je bil zapolnjen marsikateri zgodovinopisni manko, tudi v primerjavi z zgodovinopisji sosednjih držav, predvsem italijanske in

* dr., redna profesorica, Filozofska fakulteta, Univerza v Ljubljani, Aškerčeva 2, SI-1000 Ljubljana, marta.verginella@guest.arnes.si 
avstrijske, kjer so se pisanja zgodovine prve svetovne vojne lotili že po njenem kon$\mathrm{cu}$, bolj intenzivno in celovito pa so $\mathrm{k}$ njej pristopili od sedemdesetih let preteklega stoletja naprej. V slovenskem zgodovinopisju ostaja med tem še vedno pomanjkljivo raziskani del vojnega dogajanja, ki zadeva civilno prebivalstvo.

V razpravi Ženske v prvi svetovni vojni je Marija Wakounig zapisala, da v knjigah, ki govorijo o prvi svetovni vojni, marsikdaj zaman iščemo ženske. In to ne le v Sloveniji, temveč tudi drugod po Evropi. Omenjene so le fragmentarno, skorajda anekdotično, ${ }^{1}$ pa čeprav so kot delavke, kmetice, bolničarke, begunke, ${ }^{2}$ žrtve vojnega opustošenja, ki jih je prizadelo tudi sovražnikovo barbarstvo, bile del vojaške zgodovine vélike vojne. ${ }^{3}$

Zgodovinarji, ki so po koncu vojne začeli osvetljevati vojno dogajanje, in pisci vojaških spominov so večinoma zamolčali milijone delavk, uradnic, dobrotnic, sester, ki so delovale v podporo vojski in bile vključene v vojaško ekonomijo. Prvo plaho zanimanje zanje se je začelo pojavljati v šestdesetih letih, ko se je mlajša generacija zgodovinarjev začela ukvarjati s socialno zgodovino. Bolj sistematično se je nadaljevalo $\mathrm{v}$ sedemdesetih in osemdesetih letih, ko se je povečalo ukvarjanje z zgodovino žensk. Še posebej v Angliji so raziskave Gail Braybon, ${ }^{4}$ Deborah Thom ${ }^{5}$ in Arthurja Marwicka ${ }^{6}$ preučile spremembe, ki jih je vojna prinesla v zaledje, in ženski angažma v podporo vojne, delovanje bolniških sester, pa tudi prisotnost prostitucije $v$ neposredni bližini fronte. Začeli so se tematizirati in analizirati odnosi med spoloma v vojnem času, ženske alegorije in mite, ki jih je o ženskah kot užaloščenih vdovah in žalujočih materah širila vojaška propaganda. ${ }^{7}$ Tematika žensk je končno dobila mesto v obsežnih vojaških enciklopedijah ${ }^{8}$ in pregledih zgodovine žensk. ${ }^{9} \mathrm{~V}$ ameriškem zgodovinopisju so položaj žensk v véliki vojni začeli raziskovati Margaret

1 Marija Wakounig, "Ženske v prvi svetovni vojni, « v: Soška fronta 1916-1917: Kultura spominjanja, ur. Vincenc Rajšp (Dunaj: Slovenski znanstveni inštitut; Ljubljana: Založba ZRC, ZRC SAZU, 2010), 45

2 V slovenskem časopisu v času vojne in tudi po njenem koncu je še posebej izstopajoč lik begunke.

3 Françoise Thébaud, "Donne e identità di genere, « v: La prima guerra mondiale, II, ur. Stéphane Audoin-Rouzeau, Jean Jacques Becker in Antonio Gibelli (Torino: Einaudi, 2007), 35.

4 Gail Braybon, Women Workers in the First World War: The British Experience (London, Totowa, N. J.: Croom Helm, Barnes \& Noble, 1981). Gail Braybon in Penny Summerfield, Out of the Cage: Women's Experiences in Two World Wars (London: Methuen (Pandora Press), 1987).

5 Deborah Thom, "Women and Work in Wartime Britain, "v: The upheaval of war: Family, Work and Welfare, ur. Richard Wall in Jay Winter, (Cambridge: Cambridge University Press, 1988), 297-326.

6 Arthur Marwick, The Deluge: British Society and the First World War (London: Macmillan, 1965).

7 Margaret Randolph Higonnet, Jane Jenson, Sonya Michel in Margaret Collins Weitz, ur., Behind the Lines: Gender and the Two World Wars (New Haven, London: Yale University Press, 1987).

8 Richard Holmes, ur., The Oxford companion to military history (Oxford: Oxford University Press, 2001).

9 Deborah Simonton, ur., The Routledge History of Women in Europe since 1700 (London, New York: Routledge, 2007). 
R. Higonnet, ${ }^{10}$ Calire Tylee ${ }^{11}$ in Belinda Davis. ${ }^{12}$ V Franciji je v osemdesetih letih ledino na tem področju orala Françoise Thébaud, ki je pri preučevanju položaja žensk v prvi svetovni vojni ugotovila, da je Francija šele "v vojni odkrila svojo žensko polovico. ${ }^{13}$ Sistematični in celovit pregled Zgodovine žensk, ${ }^{14}$ ki je izšel leta 1992 najprej $\mathrm{v}$ italijanščini, kmalu zatem $\mathrm{v}$ francoščini, pozneje pa $\mathrm{v}$ vseh najpomembnejših evropskih jezikih, vključuje njeno poglavje o ženskah v véliki vojni, ${ }^{15} \mathrm{v}$ katerem povzema dotedanja spoznanja kolegic in kolegov, ki so se tematiki posvetili tudi $\mathrm{v}$ drugih nekdaj vojskujočih se državah.

V Nemčiji se je spremembam, ki jih je vojna prinesla v življenje milijonov žensk, začela posvečati Ute Daniel, ${ }^{16}$ v Avstriji pa je o ženskah med prvo svetovno vojno pisala Edith Rigler. ${ }^{17}$

Če se je v zgodovinopisju sprva uveljavilo mnenje, da je vélika vojna korenito spremenila odnos med spoloma in da je pripomogla $\mathrm{k}$ emancipaciji žensk, se je $\mathrm{v}$ nadaljevanju pokazalo, da se je tradicionalna vloga mater in hišnih gospodinj ohranjala tudi v vojnem času. Françoise Thébaud je na primeru Francije ugotovila, da je prva svetovna vojna za moške pomenila izpostavljenost smrti in trpljenju na bojišču, ženske pa je prizadela $\mathrm{z}$ bolečino zaradi ločitve in izgube najdražjih. Prinesla je »tudi prekinitev družinskega in družbenega reda, prisiljen začetek novih aktivnosti, čas novih možnosti«. ${ }^{18}$ Zaradi pomanjkanja moške delovne sile, ki je bila vpoklicana v vojsko, so oblasti spodbujale zaposlitev žensk, vendar ženski angažma v vojni ni vodil neogibno $\mathrm{k}$ priznanju ženske enakopravnosti niti $\mathrm{k}$ dodelitvi volilne pravice ženskam. To tezo potrjujejo številni primeri od francoskega do italijanskega in ne nazadnje tudi jugoslovanskega. Ženske so v vojnem teatru igrale vlogo navideznih

10 Higonnet, Jenson, Michel in Collins Weitz, Behind the Lines. Margaret Higonnet, ur., Lines of Fire: Women Writers of World War I (New York: Plume, 1999).

11 Glej npr. Claire M. Tylee, The Great War and Women's Consciousness: Images of Militarism and Womanhood in Women's Writings, 1914-1964 (London: Macmillan, 1990).

12 Belinda J. Davis, Home Fires Burning: Food, Politics and Everyday Life in World War I Berlin (Chapel Hill: University of North Carolina Press, 2000).

13 Françoise Thébault, Les femmes au temps de la guerre de 14 (Paris: Payot, 2013), 23.

14 François Thébaud, ur., A history of women in the West, 5: Toward a cultural identity in the twentieth century (Cambridge, London: Harvard University Press, The Belknap Press, 1996).

15 François Thébaud, "La Grande Guerra: età della donna o trionfo della differenza sessuale?," v: Storia delle donne, Il Novecento, ur. François Thébaud (Roma, Bari: Editori Laterza, 2007), 25-90.

16 Ute Daniel, Arbeiterfrauen in der Kriegsgesellschaft: Beruf Familie und Politik im Ersten Weltkrieg (Gottingen: Vandenhoeck and Ruprecht, 1989).

17 Edith Rigler, Frauenleitbild und Frauenarbeit in Österreich vom ausgehenden 19. Jahrhundert bis zum Zweiten Weltkrieg (München: R. Oldenbourg Verlag, 1976). O vlogi žensk v prvi svetovni vojni v avstrijskem delu habsburške monarhije je napisanih nekaj člankov in monografij, mdr.: Maureen Healy, Vienna and the Fall of the Habsburg Empire: Total War and Everyday Life in World War I (New York: Cambridge University Press, 2004). Christa Hämmerle, Oswald Überegger in Birgitta Bader-Zaar, ur., Gender and the First World War (Basingstoke, New York: Palgrave Macmillan, 2014). Glej tudi: Walter Lukan, "Zgodovinopisje o prvi svetovni vojni, "v: Velika vojna in Slovenci: 1914-1918, ur. Peter Vodopivec in Katja Kleindienst (Ljubljana: Slovenska matica, 2005), 16-34.

18 Thébaud, Les femmes au temps, str. 22. 
protagonistk. ${ }^{19}$ Širjenje prostorov avtonomije žensk med vojno je bilo pogosto le prehodnega značaja. Družbe, ki jih je pestila vojna, so se bale velikih sprememb in prav zato je bilo vedenje in delovanje žensk vseskozi predmet analiz, sodb, karikatur, fotografij in filmov. Z njimi so se ukvarjali novinarji, zdravniki, kleriki, moralisti, politiki, varuhi javne morale, ki so tudi poskrbeli, da se je po koncu vojne vzpostavilo med spoloma "naravno stanje«. Po Margaret H. Darrow, ki je preučila francoski primer, vojna togih predvojnih spolnih stereotipov ni zabrisala, v določeni meri jih je celo okrepila. ${ }^{20}$

Drugačnega mnenja sta Allison Scardino Belzer in Ute Daniel. Prva, ki je preučila položaj žensk med vojno v Italiji, meni, da so bili protiemancipatorni učinki vojne minimalni in da je vsesplošna vojna mobilizacija vendarle koristila ženskam: ponudila jim je priložnost, da so vstopile v javno sfero, ter možnost, da so se uveljavile kot aktivne državljanke, pa čeprav le za krajše obdobje. ${ }^{21}$ Ute Daniel kot poznavalka nemškega primera opozarja na pomanjkljivost zgodovinopisnega prijema, ki pri preučevanju zgodovine žensk v vojni in merjenju ženske emancipacije v njej aplicira današnje vrednostne kategorije in pozablja na raznolikost razmer, v katerih so delovale in živele ženske bodisi v neposredni bližini bojišča bodisi v zaledju. Dinamika med "vojno fronto" (war front) in »domačo« ali "notranjo fronto" (home front) je bila kompleksna, zato pa naj bi ukvarjanje z ženskimi izkušnjami vojne pomenilo upoštevanje njihove pluralnosti. ${ }^{22}$

$\mathrm{V}$ tem smislu so zlasti študije na zahodnoevropskih tleh od devetdesetih let naprej zapolnile številne vrzeli. Pokazale so, da ženske vojne niso doživele le kot družinske matere, delavke in dobrotnice, da so mnoge, še posebej iz višjih razredov, služile domovini v vrstah Rdečega križa, organizirale humanitarno delo in pomoč vojski, da so se nekatere odločile tudi za bolj tvegane dejavnosti. Postale so vojne reporterke, vohunke, ali pa so se celo z orožjem podajale na bojišče. Iz najnovejših raziskav vidimo tudi, kako je vojna na novo opredelila koncept moškosti in ženskosti in kako so na vojno nasilje in uničenje reagirali moški in ženske. $V$ nedavno izdanem zborniku Gender and the first world war, ki so ga uredili Crista Hämmerle, Osvald Uberrer in Birgitta Bader Zaar, je eden od poudarkov na ugotovitvi, da je zgodovina žensk v prvi svetovni vojni velikokrat nedosledna in prepolna protislovij. ${ }^{23} \mathrm{Ta}$ so ne nazadnje vidna tudi v podajanju vojne izkušnje, ki jo bomo analizirali v nadaljevanju.

19 Ibid., 23. Tezo, da je bil čas pred vojno bolj naklonjen ženskam kot povojno obdobje, razberemo tudi iz navajanj v: Eric J. Hobsbawm, Fractured Times: Culture and Society in the Twentieth Century (London: Little, Brown Book Group, 2013).

20 Margaret H. Darrow, French Women and the First World War: War Stories of the Home Front (New York: Bloomsbury Academic, 2000).

21 Allison Scardino Belzer, Women and the Great War: Femininity Under Fire in Italy (New York: Palgrave Macmillan, 2010).

22 Daniel, Arbeiterfrauen in der Kriegsgesellschaft.

23 Hämmerle, Überegger in Bader-Zaar, Gender and the First World War. 


\section{Slovenke o vojni}

Čeprav je bila v milijonski množici pisem, ki so romala z evropskih bojišč v zaledje in iz zaledja na fronto, veliko takih, ki so jih napisale ženske, hranijo tako javni kot zasebni arhivi predvsem korespondence moških. Podobno velja tudi za spomine in vojne kronike. Večinoma jih je napisala moška roka. Toda kot nam potrjujejo navedbe iz moških pisem, so si z možmi, sinovi, očeti in brati dopisovale njihove žene, matere, hčere ali sestre. Znano je tudi, da so si pisanja sposobna dekleta dopisovala z neznanimi branilci domovine in da so to navado spodbujale vojaške oblasti skorajda v vseh vojskujočih se državah.

Eden redkih primerov ohranjenih družinskih korespondenc v slovenščini, ki nam omogoča analizo doživljanja vojne tako s strani moških kot žensk istega družinskega jedra, je korespondenca družine Gerbec iz Kambreškega, ki jo hrani Pokrajinski arhiv Nova Gorica. ${ }^{24}$ Sestavljajo jo pisma in dopisnice, ki sta jih sestri Marija in Amalija pisali iz begunstva v mestu Diano Marina v Liguriji, kjer sta bivali s starši Jožefom in Marijo, medtem ko so bili bratje Mihael, Franc, Anton in Janez vpoklicani v avstro-ogrsko vojsko. Med njimi je le Mihael preživel vojno. ${ }^{25}$ Pomembna nota dopisnic, ki sta jih sestri Gerbec pošiljali preko Rdečega križa na avstrijsko stran, je globoka vera v božjo previdnost. Brate sta vseskozi spodbujali, naj tudi ob najhujši stiski in nevarnosti ohranijo zaupanje v vero in Boga. Pri svojem pisanju sta zelo skrbeli, da ne bi spodbudili cenzure in da se ne bi zaradi neprimerne vsebine prekinila komunikacijska vez, ki je bila za vse družinske člane ključnega pomena.

Več zanimivega ženskega avtobiografskega gradiva iz časa vojne je shranjenega $v$ Rokopisnem Oddelku NUK-a, ki hrani avtobiografsko gradivo priznanih ženskih peres. ${ }^{26} \mathrm{~V}$ njem so se ohranila pričevanja slovenskih izobraženk o prvi svetovni vojni. Slednje so o svojih vojnih izkušnjah pisale večinoma fragmentarno, vojnih razmer niso podrobneje opisovale, podobno so se izogibale splošnim sodbam o vojni moriji. Zato pa izpade izjemno dragocen tipkopis ${ }^{27}$ Alme Karlin (1889-1950), ${ }^{28}$

24 SI PANG 1018, Družina Gerbec, t. e. 23.

25 Petra Svoljšak, Slovenski begunci v Italiji med prvo svetovno vojno (Ljubljana: Zveza zgodovinskih društev Slovenije, 1991), 30. Petra Svoljšak, "Slovenske begunske družine v prvi svetovni vojni: Korespondenca begunske družine, "v: Vojne na Slovenskem: pričevanja, spomini, podobe, ur. Maja Godina Golja (Ljubljana: Založba ZRC, ZRC SAZU, 2012), 14-15. Slednji trije so padli v vojni. Zapuščina vsebuje poleg pisem še dnevnike in vremenske kronike, ki segajo vse do leta 1947. Korespondenca iz časa med in po prvi svetovni vojni (1915-1921) obsega 189 dopisnic in pisem Rdečega križa. Največji del predstavljajo dopisnice, ki jih je družina pisala iz Italije (88), ob njih pa še pisma prijateljice Gerbčevih hčera, begunke v taborišču Bruck ob Litvi v Spodnji Avstriji Katarine Pušnar iz Kranjske (52), Gerbčevega sina Mihaela iz avstrijske vojske (36), ostale dopisnice pa so različnega izvora (13).

26 Na primer: NUK, Rokopisni oddelek Ms 1113 KVEDER, Zofka; Ms 1175 BARTOL - NADLIŠEK, Marica; Ms 1906 PRUNK, Ljudmila.

27 NUK, Rokopisni oddelek, Ms 1872, KARLIN, Alma.

28 Več o Almi Karlin glej: Miriam Drev, »Alma Karlin: nemško-slovenska pisateljica, poliglotka in raziskovalka eksotičnih tujih svetov, "v: Pozabljena polovica: portreti žensk 19. in 20. stoletja na Slovenskem, ur. Alenka Šelih (Ljubljana: Tuma, SAZU, 2012), 234-37. 
ki je nastal na osnovi vojnega dnevnika. ${ }^{29} \mathrm{~V}$ njem je celjska popotnica in pisateljica opisala svojo vojno izkušnjo v Angliji, obdobje, ki ga je med vojno preživela na Norveškem in Švedskem, ter vrnitev prek Berlina in Prage v rodno mesto Celje. ${ }^{30} \mathrm{~V}$ svojih spominih na vojni čas pokaže s prstom na tiste, ki so bili po njenem odgovorni za izbruh vojne: »Tistega razgibanega julija so odpovedali vsi. V glavah so imeli najbolj pustolovske predstave o modernem vojskovanju, precenjevali in podcenjevali so tisto; kar še niso nikoli preizkusili; niso slutili niti, kako dolgo bo trajal spopad niti koliko trpljenja bo povzročil. «1 $\mathrm{V}$ negotovosti dogajanja in lastne usode, zapuščena v sovražni deželi brez vsakršne politične zaščite, je kot »alien enemy« občutila porast sovraštva, učinek vojnega propagandnega stroja, ki je širil »obsedenost z eno samcato mislijo«, množično psihozo, ki so se je le redki »zelo trdni značaji« ubranili. ${ }^{32}$ Kot Avstrijka je bila izpostavljena hišnim preiskavam, zlobnim pripombam, nekorektnemu zmanjšanju plače, in vendar se ni prepustila razpihovanju vojnega sovraštva. Kot "tujka iz sovražne države« je imela svoje mnenje, a se je raje ovila v molk: "V teh mesecih mojega bivanja v Londonu sem se naučila molka. Do neke mere sem to obvladala vse svoje življenje, vendar je bilo takrat težje. Nikakor se nisem navduševala nad običajnim patriotizmom - v vojni 20. stoletja sem videla preveliko krivico, grozljivo nazadovanje kulture, ki ni imelo nobenega opravičila - vendar sem bila jezikovno navezana na nemški narod in sem predobro poznala neomajno lagodnost Avstrijcev, da bi lahko trpela laži o njih. Kljub temu sem morala molčati, saj razgreta besedna bitka ne bi spremenila mnenja, ki so ga imeli o mojem narodu politični nasprotniki.«33

Njeno končno mnenje o londonski izkušnji vojne vključuje tudi pozitivne plati; ne le da so Angleži z njo ravnali dobro, nekateri so ji izkazali tudi podporo in solidarnost. V času, ki je klical po nasilju, je Alma Karlin za razliko od vojne opitih množic gojila pacifizem. Ni se pustila oslepiti od patriotizma, narodnega samoljubja, zato tudi ni mižala "pred prisilo, surovostjo in nepoštenostjo", ki so se kot plev razrastle med vojno ne le na tujem, temveč tudi v njeni domovini: „Čim si vstopil v bolnišnico ali šel skozi vlake, ki so vozili z bojišča v zaledje in jim ni bilo videti konca, si videl neskončno bedo. Kje sta veličina in lepota, o kateri sanjarijo vojni navdušenci? Kako naj bo tolikšen padec morale, ki traja še danes, očiščujoča železova kopel, o kateri so toliko čenčali? «34 Še posebej ob povratku domov je videla vso grozoto vojne na poha-

29 Marijan Pušavec, "Urednikov predgovor,"v: Sama: iz otroštva in mladosti (Celje: In lingua, 2010), 3. Marijan Pušavec, urednik slovenskega prevoda dela Ein Mesch wird... aus Kindheit und Jugend ugotavlja, da je "okvir slovenske književnosti v primeru Karlinove zajet le pogojno, ustrezneje bi jo bilo obravnavati v precej šrršem okviru književnosti v nemškem jeziku (ki se ne povezuje nujno s pripadnostjo nemški narodnosti), kamor bi celjska pisateljica zaradi jezika, v katerem je pisala, sodila po logiki stvari."

30 Svetlana Slapšak, "Potovanje pred pisanjem: avtobiografija Alme Karlin, "v: Sama: iz otroštva in mladosti (Celje: In lingua, 2010), 310. Avtobiografijo Alme Karlin Svetlana Slapšak obravnava kot eminentno feministično besedilo.

31 Alma Karlin, Sama: iz otroštva in mladosti (Celje: In lingua, 2010), 226.

32 Ibid., 227.

33 Ibid., 229.

34 Ibid., 281. 
bljenih ljudeh. Začutila je nesmiselno blaznost vojne, pokvarjenost, ki se je razrasla v vse družbene pore in je prihodnjim rodovom »sesula v prah čudovite reči .35

Avtobiografsko podajanje izkušenj, opažanj in razmislekov Alme Karlin nas seznanja z ženskim subjektivnim razumevanjem vojnega spopada, ki je ne le zaradi pacifistične naravnanosti, temveč predvsem zaradi odločnosti izreke lastnega mnenja tudi o vojni subverziven. Subverziven je nazadnje tudi zato, ker ga je jeseni 1931, ko je Alma Karlin dokončala svojo avtobiografsko knjigo, namenila »številnim ženskam tega sveta, saj bodo iz nje razbrale več, kot je zapisano med skopimi besedami, ki so vedno podobne krhkemu listju. In morda bo ravno nenapisano okrepilo dušo, ki se bori.«36

Kot vidimo iz predgovora h knjigi, se je pri podajanju lastne zgodbe po eni strani soočala s potrebo po vzpostavitvi primerne razdalje do »Jaza, ki omogoča vsaj pogojno neosebno presojo «, po drugi strani se je morala tudi odločati o tem, kaj izpustiti in kaj vključiti, "da po eni strani ne bi motili razumevanja razvoja in po drugi strani ne bi z duše odgrnili zadnje tančice, ki jo ženska vedno razprostira čez svoja najintimnejša in najgloblja občutenja. «" Izbire, ki jih je naredila, zgovorno pričajo o tem, da je bil njen namen preseči izključno intimistično pisanje in v delu, ki govori o vojnem času, spregovoriti o vojni tudi s širšega političnega vidika.

$S$ podobnimi vprašanji tkanja spominov in narativnega oblikovanja doživetega so se ukvarjale tudi slovenske izobraženke, ki so prvo svetovno vojno preživele v Trstu, in so o njej pisale v svojih spominih ter avtobiografskih zapisih. Gre za narodno oziroma v ženskih vrstah aktivne ženske Marijo Kmet, Ilko Vašte, Marico Nadlišek, Pavlo Hočevar, ki jih je močno zaznamovala učiteljska izkušnja, ${ }^{38}$ ter delovanje v slovenskih tržaških liberalnih ali socialdemokratskih krogih. Prvi so imeli svoje središč v prostorih Narodnega doma, drugi v prostorih Društva Ljudski oder. ${ }^{39}$ Razlika $\mathrm{v}$ političnem nazoru jim ni preprečila sodelovanja pri dobrodelnih dejavnostih in predvsem v Zavodu sv. Nikolaja, ki je od leta 1889 organiziral pomoč in zaposlitev v hišnih gospodinjstvih v Trst priseljenih deklet. ${ }^{40}$ Prvo svetovno vojno so torej doživele v podobnih političnih, socialnih, gospodarskih in kulturnih razmerah, $\mathrm{v}$ mestu, ki je bilo v neposredni bližini soške fronte izpostavljeno bombardiranju

35 Ibid., 280.

36 Ibid., 4.

37 Ibid., 4.

38 Marica Nadlišek je že pred vojno ob poroki z Gregorjem Bartolom zapustila učiteljski poklic.

39 Marko Kravos et al., Narodni dom v Trstu 1904-1920 (Trst: Devin, 1995). Boris Gombač, „Slovenska politika v Trstu pred prvo svetovno vojno, "Zgodovinski časopis 33, št. 2 (1979): 246-61, še posebej 254-55.

40 Zavod je kot zavetišče za brezposelne služkinje nastal po eni strani iz potrebe po zaščiti najšibkejšega člena ženske delovne sile, predvsem kmečkih in delavskih deklet, ki so iskale v mestu zaposlitve, po drugi pa iz nuje po narodnem delovanju na družbenem obrobju, kjer je bilo treba zajeziti ženske prestope $\mathrm{v}$ italijanski narodni tabor. Kljub narodnoobrambni naravi Zavoda in zavezanosti njegovih pobudnic slovenstva je bil odprt tudi dekletom drugih narodnosti. Obiskovalkam je nudil raznovrstne tečaje, pomoč pri iskanju službe in socialno zaščito v času čakanja na zaposlitev. Več v: Marta Verginella, Ženska obrobja (Ljubljana: Delta, 2006), 136-56. 
italijanskih Capronov. ${ }^{41}$ Nekatere so bile samske, druge poročene. Tiste, ki so bile zaposlene, so poučevale v Ciril-Metodovi šoli. ${ }^{42}$ Srečevale so se na istih mestih, v šoli, ob javnih kulturnih dogodkih in pri karitativnih nabirkah. Kljub podobnim vojnam izkušnjam je podajanje doživetega med vojno subjektivno, zaznamovano z osebno izkušnjo, povojnimi pripadnostmi in avtobiografsko namero. Skupna pa jim je bila marsikatera zadrega, ki so si jo pri podajanju vojne izkušnje delile z moškimi pisci. Zadrega se je pojavljala zaradi spreminjajočih se političnih razmer, ki jih je sprožila vojna, razmer, v katerih dejanja posameznikov niso bila vedno dosledna z njihovimi političnimi čutenji in prepričanji.

Učiteljica Marija Kmet (1891-1974), ${ }^{43}$ ki jo je vest o smrti prestolonaslednika doletela v kavarni Balkan, v svojih spominih ne posveča večje pozornosti žalni svečanosti in pogrebu Franca Ferdinanda, ki sta močno pretresla tržaško javnost. O tem, ali je tudi ona stopila v središče mesta, kjer se je na ulicah gnetla množica, da bi se poslovila od prestolonaslednika in njegove soproge, ${ }^{44}$ ni v njenem pisanju nikakršne sledi. Omenja pa, da je ob vojni napovedi upala, tako kot tudi kolegice in prijatelji, $s$ katerimi se je družila, da bodo Trst zasedli Angleži in da bo mesto postalo prosta luka. Svoje spomine na prvi dve leti vojne je strnila v nekaj povedi:

"Z veseljem smo pričakovali teh dni - želeli Avstriji konca in Nemcem poslednjo uro. $\mathrm{Pa}$ je baš nas v Trstu vojna močno zadela, in Avstrije ni hotelo biti konec. Vse se je preokrenilo, ko je še Italija napovedovala vojno. V tistih dneh je žarel Trst v plamenih. Strahotne so bile noči, ko je drvela množica s krikom in besnim tuljenjem po ulicah, naskakovala hiše, trgovine, kavarne, društvena in časopisna poslopja Italijanov. Priča sem bila teh dogodkov in še danes me strašijo v sanjah. Metali so pohištvo na ulice, ga polivali s petrolejem, zažigali tik plinovk, rjoveli, plenili, kradli vsevprek. Stražniki so se skrivali in izginjali v temne ulice; koder je bil največji hrup, ondi jih ni bilo videti. Rezko je udarjal duh po ognju po cestah, stebri plamenov so se dvigali in razžarjali hiše. Ista drhal, ki je zdaj vpila: 'Smrt Italiji!' je vzklikala nekaj let kasneje z istim navdušenjem: 'Živela Italija!' In vse je bežalo, begunski vlaki so se polnili; tudi naše učiteljstvo se je zbalo, odšlo je za tiste dni in malo nas je ostalo v Trstu. Nekaj tednov smo bili odrezani od drugih krajev in občutila sem tesnobo takih dni in doživela, kaj se pravi, če ni kruha in kaj, če je človek resnično lačen, pa nima kaj jesti.

41 Italijanska letala so bila poimenovana po tovarni, ki jih je izdelovala. Ustanovil jo je Giovanni Battista Caproni.

42 30. januarja 1887 so tržaške Slovenke ustanovile v Trstu žensko podružnico šolskega društva sv. Cirila in Metoda, da bi z njo podprle razvoj slovenskega šolstva v mestu in njegovi okolici. Organizirale so zbiranje sredstev za siromašne otroke in mladino, kulturne in dobrodelne prireditve, na katerih so obdarjale najrevnejše otroke, predvsem pa so se zavzemale za širjenje narodne vzgoje in gojenje slovenskega maternega jezika.

43 Katja Mihurko Poniž, "Marija Kmet: avtorica depresivne proze, ki se je reševala z vero in verjetno utihnila zaradi strogih kritik, "v: Pozabljena polovica: portreti žensk 19. in 20. stoletja na Slovenskem, ur. Alenka Šelih (Ljubljana: Tuma, SAZU, 2012), 243-46.

$44 \mathrm{O}$ vzdušju, ki je v Trstu vladalo po sarajevskem atentatu in ob pogrebnem sprevodu prestolonaslednika in njegove soproge: Borut Klabjan, "Od Trsta do Sarajeva in nazaj: Dinastična lojalnost in nacionalna pripadnost v Habsburškem Trstu na predvečer vojne, «Acta Histriae 21, št. 4 (2013): 749-72. 
Polegli so se hrupi drhali, umirile strasti nalašč za to najetih in plačanih ljudi. Prišla je tista dolga, pusta, žalostna doba vojne. $V$ Trstu smo jo močno občutili. Naši šolski otroci so navzlic raznim dobrodelnim poizkusom bledeli od dneva do dneva in pravega pouka ni bilo nič več. V šolski kuhinji smo dobivali hrano otroci in učiteljstvo in povrnila sem se nekako $\mathrm{v}$ ona mariborska leta težkih želodčnih vprašanj. Vendar priznam, da se baš meni ni godilo najhuje, ker sem dobivala prispevkov iz srečnejših slovenskih krajev. Tako so se telesne skrbi umaknile in je vnovič zaživela notranjost, ki se ni zmenila za vojno. « 45

Omemba pouličnega nasilja, ki je izbruhnilo, ko je Italija napovedala vojno Avstriji, ${ }^{46}$ ni naključna. Njegove pobudnice so bile predvsem ženske iz najnižjih slojev, ki so prebivale $\mathrm{v}$ delavski in pretežno $\mathrm{s}$ slovenskim prebivalstvom poseljeni četrti sv. Jakoba, kjer je bila tudi ena od dveh Ciril-Metodovih šol. In prav pri Sv. Jakobu se je začelo ropanje, obračunavanje in uničevanje lastnine italijanskih patriotov, ki se je nadaljevalo vse do najožjega mestnega središča. ${ }^{47}$ Drugi poudarek avtorice je na pomanjkanju hrane, ki je v ospredju tudi drugih avtoric. Zanimivo pa je, da Marija Kmet povsem zamolči svoj angažma v tržaških dobrodelnih ženskih organizacijah, predvsem pa svoje prizadevanje, da bi se širša slovenska javnost zavedala dramatične usode primorskih begunk in krivičnega odnosa, ki so ga bile te deležne v osrednji Sloveniji. ${ }^{48}$

Nekoliko daljše se o vojnih razmerah v Trstu in tegobah, ki jih je doživljala v vojnem času, razpiše v svojih spominih Ilka Vašte (1891-1967). ${ }^{49}$ Izbruh vojne jo je doletel v Bohinjski Bistrici. Tam je bila priča vpoklicu vojaških obveznikov, in bojazen, da bo moral tudi njen mož na galicijsko fronto, se je izkazala za realno v mesecu dni: "Edina tolažba $\mathrm{v}$ tistih strašnih dneh in nočeh mi je bilo to, da ni šel v vojno kot strelec, kot nemški suženj - ubijalec, ampak kot pomočnik vsem trpečim, kot spremljevalec prijatelja zdravnika dr. Jožeta Tavčarja, kot njegov nosilec obvez, instrumentov in zdravil. Bil je v krvavi bitki pri Grodeku, kjer so Rusi napodili Avstrijce proti trdnjavi Přemyzsl. Tekel je v strašni gneči in zmešnjavi zdržema triindvajset ur. Le v časih se mu je posrečilo, da se je za nekaj sto korakov oprijel kakšnega voza, ki je drvel mimo njega. Kdor je pomagal, so ga pomendrali. Vzdržali so le najmočnejši in najspretnejši. " 50 Mož se je z bojišča vrnil bolan. V nadaljevanju pa je poskrbel, da ga zaradi prekomerne teže niso ponovno vpoklicali. Ilka, ki je po rojstvu hčerke Save močno oslabela, se je morala umakniti za nekaj mesecev na podeželje v Zagorje, kjer

45 Marija Kmet, Moja Pota (Groblje: Misijonska tiskarna, 1933), 69-71.

46 Prvi nemiri so v Trstu izbruhnili zaradi pomanjkanja hrane in visokih cen med 20. in 23. aprilom 1915. Novi val je sledil italijanski vojni napovedi 23. maja 1915 in je trajal vse do 25. maja.

47 Lucio Fabi, Trieste 1914-1918: Una città in guerra (Trst: MGS Press, 1996), 23-24.

48 Marija Kmetova, "O počitnicah na Dolenjskem, « Slovenski narod, 1. 12. 1916.

49 Miriam Drev, »Ilka Vašte: pisateljica, ki je slovensko preteklost prestavila v povesti iz davnih dni, «v: Pozabljena polovica: portreti žensk 19. in 20. stoletja na Slovenskem, ur. Alenka Šelih (Ljubljana: Tuma, SAZU, 2012), 266-69.

50 Ilka Vašte, Podobe iz mojega življenja (Ljubljana: Mladinska knjiga, 1964), 115. 
je laže okrevala. Te izkušnje ni popisala, je pa vzdušje, ki ga je v vojnem času doživela v Trstu, povzela v naslednjih povedih:

"Štiri leta je visel Damoklejev meč nad mojo srečo. Med tem časom sem živela le za svoj poklic in svoj dom, za moža in dva otroka. Politike, ki se mi je v tistih klerikalno žandarskih časih gnusila, sem se izogibala. Kljub temu je malo manjkalo, da me ni kmalu v začetku vojne zasukala v svoj vrtinec.

$\mathrm{V}$ vseh skoraj sedmih letih, ki sem jih prebila v Trstu, se spominjam enega samega primera, ko je podel človek poizkušal v našo šolsko skupnost vnesti »katoliške metode«, ki so bile v navadi na Kranjskem. Ovadil nas je v začetku vojne avstrijski vojaški oblasti kot »srbofile«, ki se v njegovi odsotnosti pri zaklenjenih vratih pogovarjamo o svoji izdajalski politiki. Spravil nas je v nevarno preiskavo. Stara avstroogrska vojaška oblast v veleizdajniških zadevah ni poznala šale.

Toda možak se je uštel. Preiskavo so odstopili politični oblasti. Zasliševal nas je človeško sposoben, pameten Lah, glavar Fabrizzi, po srcu najbrž nasprotnik razmajane Avstroogrske. « 51

V spominjanje na vojni čas je Ilka Vašte vključila še dve pomembni anekdoti. Prva je povezana $\mathrm{z}$ dobrodelno prireditvijo in z osamitvijo, ki so jo v slovenskem tržaškem okolju doživeli srbofili. Piska se spominja žene dr. Žerjava, aretiranega kot srbofila in avstrijskega izdajalca, ki je sedela povsem sama v dvorani Balkana, ne da bi se ji nihče približal. Slovenske družba se je takrat "potuhnila pred avstrijskim policijskim bičem. "52 Druga anekdota zadeva Cankarjevo predavanje v Trstu marca 1918. ${ }^{53}$ Organizatorji dogodka so slovenskega pisatelja zadržali v hiši dr. Ferfolje, da bi ostal trezen: "Rada bi bila šla poslušat njegovo predavanje, toda nisem mogla, ker so mi skupaj z gospo Maro Rusovo naprtili skrb za bife na čajanki, ki smo jo na skrivaj, to se pravi: brez blagoslova oblasti priredili Cankarju na čast v stranskih prostorih hotela Balkan. Ne spominjam se, da bi se bil tiste neuradne čajanke udeležil kdo izmed tržaških političnih 'prvakov'. "54 $\mathrm{O}$ omejitvah, ki jim je bila v vojnem času izpostavljena, izvemo le iz drobnih omemb, ko denimo zapiše, da v letih vojne ni rada hodila po nepotrebnem od doma, ker se je zaradi bombnih napadov bala puščati otroka sama pri služkinji. 55 Živela je namreč v stavbi, ki je bila v bližini vojaške bolnišnice in vojašnice, obe stavbi pa sta bili tarči sovražnikovih letal.

Bolj podrobno o bobnenju letal in sovražnih bombah, ki so jih nad Trst spušča-

51 Ibid., 117. Opis istega dogodka in zagovora pred komisarjem tudi v: Pavla Hočevar, Pot se vije: spomini (Trst: Založništvo tržaškega tiska, 1969), 98-99.

52 Vašte, Podobe iz mojega življenja, 118,

53 Ivan Cankar je predaval v Trstu 10. marca 1918 v Društvu Ljudski oder. Predavanje je izšlo z naslovom Očiščenje in pomlajanje. Glej: Marija Pirjevec, »Ivan Cankar in Trst, «Jezik in slovstvo 22, št. 3 (1976): 65-71.

54 Vašte, Podobe iz mojega življenja, 119. Čeprav je imel Cankar predavanje v prostorih Društva Ljudski oder, je pogostitev sledila v Narodnem domu, kar lahko razumemo kot potrditev sodelovanja med socialdemokratsko in liberalno orientiranimi slovenskimi izobraženci, ki pa ni uživalo podpore slovenskega liberalnacionalnega vodstva.

55 Ibid., 121. 
li italijanski Caproni, piše v svoji avtobiografiji ${ }^{6}$ Marica Nadlišek Bartol (18671940), ${ }^{57}$ nekdanja urednica Slovenke, prvega slovenskega ženskega časopisa: »Bile so prve bombe. Odslej ni bilo več ne dneva ne noči, da bi ne leteli nad nami sovražni zrakoplovi, ki so prihajali od Opčin sem, krožili in se razgledovali. Ko so se že vračali in bili skoraj že za obzorjem, šele tedaj so se dvigali avstrijski izza Žavelj za njimi. Večkrat smo se seveda temu smejali. Lepe poletne noči so začele v samih reflektorjih, ki so baje iskali sovražnika v zraku. Žarometi so švigali zdaj po nebu zdaj po tleh na vse strani. Dasi vsa izmučena in utrujena, služkinje nisem več mogla imeti, ker je bilo pomanjkanje hrane že občutno sem legla v posteljo. ${ }^{58}$ Kot mati petih otrok je vojno občutila še posebej dramatično, zato se je tudi v svoji avtobiografski pisavi posvetila opisu "grozovitosti šibe božje«. Pomanjkanje najosnovnejše hrane jo je prisililo, da je kljub svoji zavezanosti meščanskemu slogu življenja kupila kozo in jo prinesla v svoj meščanski dom. Svojim otrokom je morala zagotoviti prepotrebno mleko. Toda bolj peresa kot molže vešča ženska z njo ni rešila težav pri prehranjevanju otrok. Prisiljena je bila oditi po živež na Dolenjsko. Enega od sinov je sicer rešila pred pomanjkanjem in smrtjo tako, da ga je z drugimi svetoivanskimi otroki odpeljala v Varaždin, ${ }^{59} \mathrm{kjer}$ je bilo lokalno prebivalstvo pripravljeno sprejeti »na hrano" otroke iz Trsta in s Krasa: "Tu niso nič vedeli o grozotah vojne, o bombah in zrakoplovih, o pomanjkanju in gladu. Kakor da smo prišli v drug svet. Bel kruh, obilo mesa, klobas, pečenke, z eno besedo vsega, o čemer smo mogli mi siromaki samo še sanjati. Videli smo, jedli smo, a verjeti nismo mogli, da je vse to res, da more biti taka razlika med državljani iste države. Da, Ogrska je vse trdno držala v svojih krempljih in ni dala prav nič na noben pritisk. Sinka sem pustila v Varaždinu, kjer se mu je dobro godilo in si je kmalu opomogel. Z županovim dovoljenjem sem lahko odnesla nekaj moke in slanine ter nastopila težko pot proti domu. «60

Po prihodu domov jo je še bolj bodlo v oči pomanjkanje, $\mathrm{v}$ katerem so živeli v Trstu. V spominu ji je ostalo obilje hrane, ki ga je videla na Hrvaškem, in zato so se ji razmere, v katerih so živeli v neposrednem zaledju fronte, zdele še bolj krivične: "Tu sama ovsena kaša brez zabele, tam na Hrvaškem pa imajo vsega v izobilju. Kje je pravica, sem si mislila. Pri nas umirajo ljudje od gladu, v Istri jedo nekateri kar

56 Pisanja spominov na svoja tržaška leta se je Marica Nadlišek Bartol lotila leta 1927, zaključila pa poleti 1938. V prvoosebni pripovedi je opisala okolje, v katerem je odraščala, študirala in potem delovala kot učiteljica, pisateljica in urednica Slovenke. Avtobiografija Iz mojega življenja je leta 1948 izšla v nadaljevanjih v tržaških Razgledih, ki jih je urejal njen sin Vladimir Bartol. Leta 2005 je bila natisnjena v knjigi Na Obali: kratka proza. Tipkopis hrani Odsek za zgodovino in narodopisje pri Narodni in študijski knjižnici v Trstu, in sicer v Biografskem arhivu (fasc. Marica Nadlišek Bartol).

57 Marta Verginella, "Marica Nadlišek, por. Bartol (1867-1940): urednica Slovenke, prvega slovenskega ženskega lista, učiteljica, pisateljica, publicistka, prevajalka," v: Pozabljena polovica: portreti žensk 19. in 20. stoletja na Slovenskem, ur. Alenka Šelih (Ljubljana: Tuma, SAZU, 2012), 139-41.

58 Marica Nadlišek Bartol, Na Obali: kratka proza (Trst: ZTT - EST, 2005), 333.

59 Hočevar, Pot se vije: spomini, 97. Da je šlo za organizirano pobudo, izvemo iz spominov Pavle Hočevar, ki navaja, da je po posredovanju Antonije Slavik Rdeči križ organiziral kolonijo otrok v Švici ob spremestvu Milke Martelanc, podobno tudi bivanje otrok pri hrvaških družinah v okolici Varaždina, kamor so prišli "tako sestradani in oslabljeni, da so jih plemenite hrvatske kmetice dobesedno rešile smrti."

60 Nadlišek Bartol, Na Obali: kratka proza, 337. 
travo, da jim zatekajo noge, ki postanejo kakor tramovi, dokler jih ne reši smrt, tam pa se maste in rede z vsem dobrim. [...] Stari in oslabeli ljudje so cepali in umirali kar na ulicah; sestradani in utrujeni konji so se kar zleknili in poginili na cestah. Od gladu so umirali otroci, tudi med mojimi sorodniki v Koloniji, kjer sem se rodila, so našli zjutraj mater umirajočo in otroka mrtvega. Jaz nisem več upala, da mi vsi otroci ostanejo živi. Drugega sina so vzeli moževi sorodniki v Medvode, da je imel jesti in da je nam ostala njegova nakaznica. ${ }^{61}$

Militarizacija moža leta 1916 in višja plača majorja, ki jo je potem prejemal, ni bistveno spremenila družinskih materialnih razmer, za kar je Marica krivdo pripisovala tudi sebi: »Leta 1916 je bil mož militariziran. Dobil je čin majorja in še enkrat takšno plačo kakor doslej. Bil je pa dan za dnem vse popoldneve v kavarni, kjer so politizirali in ob kartah reševali in ustvarjali Jugoslavijo. Lahko bi tedaj plačevali oderuške cene za živež, a mož mi je dajal kakor ponavadi. Veliko krivde je na meni, ki bi morala zaradi otrok nastopiti vse drugače. "62 Marica je bila prepričana, da politične oblasti niso preganjale njenega moža in drugih jugoslovansko in rusofilsko usmerjenih tržaških Slovencev, med katere je sodila tudi sama, ker so v Trstu veljale posebne razmere. "Ko bi bila kje drugod in ne v Trstu, bi že davno ne imel več glave. Toda v Trstu je bilo vse slovensko in italijansko prebivalstvo le za antanto in proti centralnim silam, vsi ene misli, istih želja. Kaj so mogle oblasti, ki so dobro poznale naše razpoloženje. Namestnik je zatisnil kar obe očesi. Že ob začetku vojne sem pripovedovala vsem in povsod, da sta vojni krivi le Nemčija in Avstrija, da Avstrija tako sovraži Srbijo, da ji ni dovolila dohoda na morje, dasi so si ga priborili s krvjo in žrtvami v balkanski vojni.« 63

Da je v tem svojem prikazu političnega vzdušja idealizirala razmere v Trstu, vidimo iz njenih konkretnih opisov tržaške stvarnosti, še posebej pa iz ugotovitve, da se je večina tržaškega prebivalstva med vojno vedla konformistično. Tržaški trgovci, ki so ob izbruhu vojne okrasili svoje izložbe s črno-rumeno barvo, so ob prihodu italijanske vojske v mesto razkazovali italijansko trikoloro.

O življenju med prvo svetovno vojno v Trstu, ko je bil na voljo le vijoličasti kruh z okusom po plesni in je mrgolelo vohunov ter ovaduhov, piše v svojih spominih tudi Pavla Hočevar (1889-1972). Pri opisovanju vojnega časa posveča posebno pozornost političnemu vzdušju, ki je vladalo v tržaškem okolju, v katerem je delovala kot politično in narodno angažirana učiteljica: »Ko se je začela prva svetovna vojna, je z vso silo zaplalo tudi v nas nekaj novega, nedoločenega, polno groze in bojazni in - upanja. Kamorkoli sem stopila, me je spremljalo glasno ali prikrito vprašanje: kaj mislite,

61 Ibid., 336-37.

62 Podčrtani del je zapisan v originalu (Odsek za zgodovino in narodopisje pri Narodni in študijski knjižnici v Trstu, fasc. Marica Nadlišek Bartol), bil pa je prečrtan v prvi objavi v tržaških Razgledih (1948) Kritike, ki so letele na račun moža, je avtoričin sin Vladimir Bartol kot urednik tržaških Razgledov umaknil iz objave in tako je tudi nedavno objavljena verzija Iz mojega življenja, natisnjena v knjigi $\mathrm{Na}$ Obali: kratka proza, brez stavkov, ki so po Bartolovem mnenju neupravičeno metali slabo luč na njegovega očeta. Nadlišek Bartol, Na Obali: kratka proza, 337.

63 Ibid., 332. 
kaj bo zdaj z nami? Za odgovor smo drug drugemu sporočali vesti z balkanske in ruske fronte, si zaupali dobljene izjave, mnenja dobro obveščenih oseb, govorice iz italijanskih krogov ... Vse pa smo povezovali z upanjem na prihodnost, ki se nam je kazala danes temna, jutri svetla, pojutrišnjim meglena, pa zopet svetla, svetla. «64 Kot lahko sklepamo iz citata, je v avtobiografski pripovedi Pavle Hočevar viden vpliv časa, v katerem je njena avtobiografija nastala. V linearno oblikovani avtobiografski pripovedi posveča velik pomen svojemu kulturnemu in političnemu angažmaju in opozorja na politično ozadje vojne stvarnosti: » Porazi in zmage na bojiščih na Balkanu, na ruski fronti in na zahodu, oktobrska revolucija, razpad trozveze, pristop Italije $\mathrm{k}$ antanti. Jugoslovanski odbor v inozemstvu, novi cesar v Avstriji, majniška deklaracija, prodor na solunski fronti, pa novosti v preskrbi in še toliko drugih dogodkov - vse to je odvijalo in privijalo svetilko nad našim upanjem, da je zdaj plamenelo, zdaj tlelo, nikoli pa ugasnilo.« ${ }^{65}$

Podobno kot Marica Nadlišek Bartol tudi Pavla Hočevar omenja bedo, stradanje, pomanjkanje, toda le mimogrede. Zanjo je pomembnejši politični okvir, v katerem se je znašlo tržaško slovensko prebivalstvo v vojnem času. Za razliko od ostalih avtoric podaja podrobnejšo sliko ženske aktivnosti v Trstu. Piše o tem, kako so na pobudo tržaškega Rdečega križa in slovenske delegatke Antonije Slavik na Ciril-Metodovi šoli zbirali perilo, kovine, denarne prispevke. Kako je bila kot odbornica Ciril-Metodove ženske podružnice aktivna v Organizaciji za pomoč vdovam in sirotam, kako je sodelovala pri pripravi pevskih in dramskih prireditev za otroke in odrasle "Z namenom, da okrepim narodno zavest, da izpričamo razumevanje za socialne potrebe, da zberemo sredstva za pomoč našim potrebnim otrokom in družinam. « ${ }^{66}$ Pri organiziranju dobrodelne pomoči slovenskim družinam, ki jih je prizadela vojna, je podpirala delovanje Antonije Slavik, čeprav se z njo ni vedno strinjala: »Njena domoljubna čustva, so bila jasna in neomajna: veselila se je in trpela s Srbi in z Rusi in z vsemi zavezniki; iz iste globine srca pa je tudi privoščila zmago generalu Borojeviću. Nekatere med njenimi sodelavkami ji nismo mogle slediti, čeprav smo občudovale njeno brezmejno ljubezen do tega koščka slovenske zemlje. Naši pogledi na splošno vojno politiko so se večkrat razhajali in nismo si mogle kaj, da bi ji kljub spoštovanju ne bile v šali dajale vzdevka gospa harmonika.« 67

V nadaljevanju Pavla opiše hiranje otrok, njihovo pošiljanje na kmete, brezplačna kosila v šolski kuhinji na obeh Ciril-Metodovih šolah, nad 700 brezplačnih kosil pri Sv. Jakobu in nad 300 na Aquedottu, a tudi, kako je na pravljičnih popoldnevih v Slovenskem gledališču Marica Bartol pripovedovala » vesti in bajke, čarala malčkom čudežne prizore in jim bridkosti vsakdanjega življenja vsaj za neka uric spreminjala

64 Hočevar, Pot se vije: spomini, 95. Več o Pavli Hočevar (1889-1972) učiteljici, publicistiki in feministki glej: Metka Gombač, »Pavla Hočevar (1889-1972): učiteljica, publicistka, feministka, v v: Pozabljena polovica: portreti žensk 19. in 20. stoletja na Slovenskem, ur. Alenka Šelih (Ljubljana: Tuma, SAZU, 2012), 229-33.

65 Hočevar, Pot se vije: spomini, 95.

66 Ibid., 96.

67 Ibid., 96. Gospa harmonika, ker je slovenskim vojakom na fronto pošiljala harmonike. 
v svet Indije Koromandije. «68 Pavla Hočevar prikazuje vojni čas kot čas, v katerem je med slovenskim prebivalstvom naraščalo proslovansko čutenje, ki se je širilo tudi med nižje razrede. Po njenem prepričanju je v vojni tržaške Italijane in Slovence družila protiavstrijska mržnja: "Sožitje s tržaškimi Italijani, odvisnimi od Avstrije, je bilo med vojno za našo miselnost vsekakor različno od sožitja z vladajočimi Nemci. Čeprav smo bili v hudem medsebojnem sporu, je vendar nje in nas družilo nekaj skupnega: mržnja do Avstrije in pričakovanje njenega razpada. «" ${ }^{69} \mathrm{Za}$ razliko od ostalih v Trstu živečih slovenskih izobraženk se Pavla Hočevar loti zelo podrobnega opisa političnih razmer ob koncu vojne, opiše kako se je njeno upanje sprevrglo v razočaranje, kako se je slovensko učiteljstvo organiziralo po prihodu italijanske vojske v Trst. Čeprav je bolj kot ostale tu omenjene piske razumela svoje avtobiografsko pisanje "v funkciji drugih «, 70 je tudi ona izkoristila bel list, da je zapisala svoj lastni pogled na čas, v katerem je živela, in to kljub trpki izkušnji Nagodetovega procesa, ki jo je doletela. $^{71}$

\section{Zaključek}

Vse tu omenjene piske je prva svetovna vojna zaznamovala tako v materialnem kot nematerialnem smislu. In vendar, če njihov opis vojnih izkušenj in vojnih razmer ocenjujemo v okviru njihove celotne avtobiografske pripovedi, ugotovimo, da je bil zanje bolj kot vojni čas travmatičen povojni čas. Po prihodu italijanskih oblasti so slovenske izobraženke v Trstu doživele pritiske in grožnje, ki so jih prisilile v odhod in izselitev v Državo SHS oziroma Kraljevino Jugoslavijo. Ne nazadnje so prav travma prisilnega odhoda iz Trsta, okolja, v katerem so se poklicno uveljavile in našle odlične spodbude za javno delovanje, katerega odmev je segel tudi v širšo slovensko javnost, in težave, ki so jih imele pri vključevanju v novo ljubljansko oziroma širše kranjsko stvarnost, dale povod za avtobiografsko pisanje in samozavedanje prehojene življenjske poti. V njihovih naracijah prva svetovna vojna izpade kot uvertura v prihodnje katastrofe, ki so zajele Evropo, slovenski narod in njih same. Iz konkretnih opisov pa vidimo, da prva svetovna vojna zanje ni bila čas emancipacije, nadaljevanja intelektualnega in političnega dela, ki so ga opravljale pred njenim začetkom. Prisilila jih je v umik v zasebnost in k ukvarjanju z dobrodelno dejavnostjo, ki pa je bila pred prvo svetovno vojno le eno od področij, na katerem so delovale. Podobno je tudi Almi Karlin konec vojne pomenil prilagajanje novemu okolju, kjer so se razraščala nova sovraštva, ki jih je zapustila vojna.

68 Ibid., 97.

69 Ibid., 100.

70 Marie-Claire Hoock-Demarle, "Leggere e scrivere in Germania," v: Storia delle donne: L'Ottocento, ur. Geneviève Fraisse in Michelle Perrot (Bari, Rim: Laterza, 1991), 246-70.

71 Gombač, »Pavla Hočevar (1889-1972), «233. Na Nagodetovem procesu, ki je potekal leta 1947, je bila obtožena zaradi vohunjenja. Obsojena je bila na 14 let zapora, a so jo slovenske oblasti maja 1952 pogojno izpustile. Sodba je bila razveljavljena šele leta 1991. 


\section{Viri in literatura}

\section{Arhivski viri:}

- NUK, Narodna in univerzitetna knjižnica, Rokopisni oddelek:

- Ms 1113, KVEDER, Zofka.

- Ms 1175, BARTOL - NADLIŠEK, Marica.

- Ms 1872, KARLIN, Alma.

- Ms 1906, PRUNK, Ljudmila.

- SI PANG, Pokrajinski arhiv v Novi Gorici:

o PANG 1018, Družina Gerbec, t. e. 23.

\section{Časopisni viri:}

- Kmetova, Marija. „O počitnicah na Dolenjskem.«Slovenski narod, 1. 12. 1916.

\section{Literatura:}

- Braybon, Gail. Women Workers in the First World War: The British Experience. London, Totowa, N. J.: Croom Helm, Barnes \& Noble, 1981.

- Bader-Zaar, Birgitta, Christa Hämmerle in Oswald Überegger, ur. Gender and the First World War. Basingstoke, New York: Palgrave Macmillan, 2014.

- Braybon, Gail in Penny Summerfield. Out of the Cage: Women's Experiences in Two World Wars. London: Methuen (Pandora Press), 1987.

- Daniel, Ute. Arbeiterfrauen in der Kriegsgesellschaft: Beruf, Familie und Politik im Ersten Weltkrieg. Gottingen: Vandenhoeck and Ruprecht, 1989.

- Darrow, Margaret H. French Women and the First World War: War Stories of the Home Front. New York: Bloomsbury Academic, 2000.

- Davis, Belinda J. Home Fires Burning: Food, Politics and Everyday Life in World War I Berlin. Chapel Hill: University of North Carolina Press, 2000.

- Drev, Miriam. »Alma Karlin: nemško-slovenska pisateljica, poliglotka in raziskovalka eksotičnih tujih svetov. V: Pozabljena polovica: portreti žensk 19. in 20. stoletja na Slovenskem. Ur. Alenka Šelih, 234-37. Ljubljana: Tuma, SAZU, 2012.

- Drev, Miriam. »Ilka Vašte: pisateljica, ki je slovensko preteklost prestavila v povesti iz davnih dni.« V: Pozabljena polovica: portreti žensk 19. in 20. stoletja na Slovenskem, ur. Alenka Šelih, 266-69. Ljubljana: Tuma, SAZU, 2012.

- Fabi, Lucio. Trieste 1914-1918. Una città in guerra. Trst: MGS Press, 1996.

- Gombač, Boris. "Slovenska politika v Trstu pred prvo svetovno vojno."Zgodovinski časopis 33, št. 2 (1979): 246-61.

- Gombač, Metka. „Pavla Hočevar (1889-1972): učiteljica, publicistka, feministka.«V: Pozabljena polovica: portreti žensk 19. in 20. stoletja na Slovenskem. Ur. Alenka Šelih, 229-33. Ljubljana, Tuma: SAZU, 2012.

- Healy, Maureen. Vienna and the Fall of the Habsburg Empire: Total War and Everyday Life in World War I. New York: Cambridge University Press, 2004.

- Higonnet, Margaret Randolph, Jane Jenson, Sonya Michel in Margareth Collins Weitz, ur. Behind the Lines: Gender and the Two World Wars. New Haven, London: Yale University Press, 1987.

- Higonnet, Margaret Randolph, ur. Lines of Fire: Women Writers of World War I. New York: Plume, 1999.

- Hobsbawm, Eric J. Fractured Times: Culture and Society in the Twentieth Century. London: Little, Brown Book Group, 2013.

- Hočevar, Pavla. Pot se vije: spomini. Trst: Založništvo tržaškega tiska, 1969.

- Holmes, Richard, ur. The Oxford companion to military history. Oxford: Oxford University Press, 2001.

- Hoock-Demarle, Marie-Claire. »Leggere e scrivere in Germania.« V: Storia delle donne. L'Ottocento. Ur. Geneviève Fraisse in Michelle Perrot, 246-70. Bari, Rim: Laterza, 1991.

- Karlin, Alma. Sama: iz otroštva in mladosti. Celje: In lingua, 2010. 
- Klabjan, Borut. „Od Trsta do Sarajeva in nazaj: Dinastična lojalnost in nacionalna pripadnost v Habsburškem Trstu na predvečer vojne." Acta Histriae 21, št. 4 (2013): 749-72.

- Kmet, Marija. Moja Pota. Groblje: Misijonska tiskarna, 1933.

- Kravos, Bogomila, Marko Kravos, Pavle Merkù, Milan Pahor, Marco Pozzetto in Sandi Volk. Narodni dom v Trstu 1904-1920. Trst: Devin, 1995.

- Lukan, Walter. "Zgodovinopisje o prvi svetovni vojni.«V: Velika vojna in Slovenci: 1914-1918. Ur. Peter Vodopivec in Katja Kleindienst, 16-34. Ljubljana: Slovenska matica, 2005.

- Marwick, Arthur. The Deluge: British Society and the First World War. London: Macmillan, 1965.

- Mihurko Poniž, Katja. »Marija Kmet: avtorica depresivne proze, ki se je reševala z vero in verjetno utihnila zaradi strogih kritik."V: Pozabljena polovica: portreti žensk 19. in 20. stoletja na Slovenskem. Ur. Alenka Šelih, 243-46. Ljubljana: Tuma, SAZU, 2012.

- Nadlišek Bartol, Marica. Na Obali: kratka proza. Trst: ZTT - EST, 2005.

- Pirjevec, Marija. »Ivan Cankar in Trst.« Jezik in slovstvo 22, št. 3 (1976): 65-71.

- Pušavec, Marijan. „Urednikov predgovor.« V: Sama: iz otroštva in mladosti. Celje: In lingua, 2010.

- Rigler, Edith. Frauenleitbild und Frauenarbeit in Österreich vom ausgehenden 19. Jahrhundert bis zum Zweiten Weltkrieg. München: R. Oldenbourg Verlag, 1976.

- Scardino Belzer, Allison. Women and the Great War: Femininity Under Fire in Italy. New York: Palgrave Macmillan, 2010.

- Simonton, Deborah, ur. The Routledge History of Women in Europe since 1700. London, New York: Routledge, 2007.

- Slapšak, Svetlana. "Potovanje pred pisanjem: avtobiografija Alme Karlin.» V: Sama: iz otroštva in mladosti, 308-17. Celje: In lingua, 2010.

- Svoljšak, Petra. »Slovenske begunske družine v prvi svetovni vojni: Korespondenca begunske družine.«V: Vojne na Slovenskem: pričevanja, spomini, podobe. Ur. Maja Godina Golja, 11-25. Ljubljana: Založba ZRC, ZRC SAZU, 2012.

- Svoljšak, Petra. Slovenski begunci v Italiji med prvo svetovno vojno. Ljubljana: Zveza zgodovinskih društev Slovenije, 1991.

- Thébaud, Françoise. "Donne e identità di genere.« V: La prima guerra mondiale. Ur. Stéphane Audoin-Rouzeau, Jean Jacques Becker in Antonio Gibelli, 35-48. Torino, Einaudi, 2007.

- Thébaud, François. "La Grande Guerra: età della donna o trionfo della differenza sessuale?.«V: Storia delle donne, Il Novecento. Ur. François Thébaud, 25-90. Roma, Bari: Editori Laterza, 2007.

- Thébaud, Françoise. Les femmes au temps de la guerre de 14. Paris: Payot, 2013.

- Thébaud, François. Ur. A history of women in the West, 5, Toward a cultural identity in the twentieth century. Cambridge, London: Harvard University Press, The Belknap Press, 1996.

- Thom, Deborah. "Women and Work in Wartime Britain. V: The upheaval of war: Family, Work and Welfare. Ur. Richard Wall in Jay Winter, 297-326. Cambridge: Cambridge University Press, 1988.

- Tylee, Claire M. The Great War and Women's Consciousness: Images of Militarism and Womanhood in Women's Writings, 1914-1964. London: Macmillan, 1990.

- Vašte, Ilka. Podobe iz mojega življenja. Ljubljana: Mladinska knjiga, 1964.

- Verginella, Marta. »Marica Nadlišek, por. Bartol (1867-1940): urednica Slovenke, prvega slovenskega ženskega lista, učiteljica, pisateljica, publicistka, prevajalka."V: Pozabljena polovica: portreti žensk 19. in 20. stoletja na Slovenskem. Ur. Alenka Šelih, 139-41. Ljubljana: Tuma, SAZU, 2012.

- Verginella, Marta. Ženska obrobja. Ljubljana: Delta, 2006.

- Wakounig, Marija. "Ženske v prvi svetovni vojni.« V: Soška fronta 1916-1917: Kultura spominjanja. Ur. Vincenc Rajšps, 43-50. Dunaj: Slovenski znanstveni inštitut; Ljubljana: Založba ZRC, ZRC SAZU, 2010. 
Marta Verginella

WOMEN IN WAR AND THEIR OUTLOOK ON THE GREAT WAR

S UM M A RY

The contribution sheds light on the historiographic research of women in World War I as well as on the individual approaches and opinions, established in the field of gender studies. It focuses on the question of the degree to which the Great War contributed to women's emancipation or, on the other hand, to the limitation of their autonomy. In the most referential historiographic studies in the last decades a conviction has asserted itself, on one hand, that women played a role of a fictitious protagonist in the theatre of war and that the expansion of the spaces of their activities during the war was often merely transitory in nature. On the other hand we can find the opinion that the Great War radically transformed gender relations and contributed to women's emancipation. Recollections of the educated Slovenian women, actively involved in the national and female cause in Trieste, confirm especially the former thesis. World War I forced Marija Kmet, Ilka Vašte, Marica Nadlišek and Pavla Hočevar to withdraw to the private sphere or limit their public activities mostly to charitable work. Their memoirs reveal what kind of material and other problems they faced, how they preserved their memories of war and how they included them in their autobiographical narration. For them World War I was an introduction to the post-war catastrophe which, for the people of the Primorska region, had started with the arrival of the Italian Army and the military occupation regime and continued with the fascist regime, which forced them to become refugees. The contribution also analyses the autobiography of Alma Karlin, who spent the war in England, Norway, Sweden, Berlin, Prague and in her hometown of Celje. In the times which called for violence and contrary to the masses, intoxicated by war, Alma Karlin supported pacifism and expressed her own opinion of war. 